\title{
O masculino e o feminino nas narrativas da cultura de massas ou o deslocamento do olhar*
}

\author{
Maria Celeste Mira**
}

\begin{abstract}
Resumo
O objetivo do texto é explorar as possibilidades de análise da questão dos gêneros na mídia através de sua articulação com as formas narrativas desenvolvidas no interior da indústria cultural contemporânea. Destacam-se neste trabalho as permanências $e$ as transformações pelas quais ambos (gêneros $e$ formas narrativas) vão passando e, assim, procura-se relacioná-los ao fator geracional.
\end{abstract}

Palavras-chave: Gênero, Narrativa, Cultura de Massa.

\footnotetext{
" Recebido para publicação em junho de 2003, aprovado em setembro de 2003.

*** Professora do Programa de Estudos Pós-Graduados em Ciências Sociais da PUC-SP
} 
o deslocamento do olhar

The Masculine and the Feminine in Mass Culture Narratives or the Displacement of the Gaze

\begin{abstract}
The aim of the text is to investigate the analytic possibilities concerning gender in the media, articulating it with narrative forms (genres) developed in contemporary cultural industry. The work shows in both gender and genre aspects that seem to be permanent and their transformations and this connects them to generational changes.
\end{abstract}

Key Words: Gender, Genre, Mass Culture. 
Embora, no Ocidente moderno, tenda a diminuir a distância que separa o mundo masculino do mundo feminino, ainda é grande a sua oposição no universo da cultura popular de massa. ${ }^{1}$ Essa diferença, que não esgota a problemática do gênero em campos mais intelectualizados, está entre as mais importantes para se compreender os produtos da indústria cultural, tanto nos seus conteúdos como em suas formas. No mercado cultural de massa, as primeiras formas de segmentação relacionam-se, normalmente, a produtos voltados para as mulheres. Nos jornais, logo aparece o suplemento feminino; na televisão, os programas femininos, o horário feminino, a TV Mulher e, finalmente, a Rede Mulher. ${ }^{2}$

Quando se trata de meios mais populares, como a televisão aberta, em geral dirigida a pessoas de pouca escolaridade, ou de pouco capital cultural, como diria Bourdieu $^{3}$, as próprias representações ligadas ao gênero são bastante tradicionais ou conservadoras, como se queira. Homossexualismo, na maioria das vezes, é motivo de piada ou de curiosidade. A bicha é uma figura

\footnotetext{
1 Utilizo os termos indústria cultural ou cultura (popular) de massas por considerá-los mais abrangentes do que o de mídia, como será explicitado mais adiante. Também não me preocupa aqui a polêmica frankfurtiana sobre as diferenças entre estes dois conceitos. A esse respeito ver ADORNO, Theodor e HORKHEIMER, Max. A indústria cultural: o esclarecimento como mistificação das massas. In: Dialética do esclarecimento. Rio de Janeiro, Zahar, 1985.

2 É claro que isto se deve ao fato de ela ter se tornado na sociedade moderna um sujeito consumidor dos mais relevantes. Desde o século XIX, a mulher burguesa, inicialmente, e depois também a de classe média, tem sido o principal alvo do mercado da moda, de todos os bens voltados para o conforto doméstico, dos produtos destinados à sedução do sexo oposto, bem como daqueles que são consumidos por seu marido e seus filhos. Mas o consumo não explica tudo. A mulher emerge como segmento de mercado ao mesmo tempo em que aparece como sujeito de sua própria história. Essa dinâmica tem se repetido constantemente. Foi o que aconteceu com os movimentos jovens, o dos negros, o da terceira idade, o GLS. Discuti essa questão em Cultura e segmentação: um olhar através das revistas, texto apresentado na XXV Reunião da Anpocs. Caxambu, outubro de 2001.

3 Bourdieu, Pierre. La distinción. Criterios y bases sociales del gusto. Madri, Taurus, 1989.
} 
o deslocamento do olhar

quase indispensável num programa humorístico e o travesti pode ser atração num programa de variedades, na linha da barraca de fenômenos e excentricidades das feiras populares dos séculos XIX e XX. Nas novelas, o homossexualismo tem aparecido, mas sempre como tema secundário. Ainda não foi levada ao ar pela televisão uma história de amor protagonizada por um casal homossexual. Ao contrário, sabe-se pelo sempre citado exemplo de Torre de Babel (Rede Globo), que um providencial incêndio pôs fim à mal vista relação entre duas mulheres. Mesmo nas telenovelas, onde o homossexualismo feminino volta a ser abordado, desta vez, ao que parece, com maior aceitação em Mulheres apaixonadas, (Rede Globo, 2003), a seriedade divide lugar com a piada. Não são poucos os personagens gays calcados na comicidade. Já no cinema e nas revistas, o espaço do homossexualismo é maior. Trata-se de mídias que se consomem de forma mais privada, onde, portanto, o problema da desaprovação social é menor. Há uma produção considerável de filmes gays, com seus festivais e tudo o mais. Há revistas cuja proposta editorial se volta para este público. Mas mesmo no universo do filme, do vídeo e das revistas, o homossexualismo se acopla mais ao campo da pornografia e, ao fazê-lo, se agrega ao universo masculino, como veremos adiante. É verdade que já se pode falar de um segmento de mercado GLS, mas não se pode dizer que haja gêneros narrativos cuja história esteja ligada à construção de sua identidade, como no caso da feminilidade e da masculinidade. ${ }^{4}$

\footnotetext{
${ }^{4}$ Dessa forma, ao falar, neste texto, em homens e mulheres me refiro sempre aos heterossexuais. Quando digo masculino e masculinidade ou feminino $e$ feminilidade, penso nas construções tradicionais, ainda hegemônicas, embora não compartilhe de uma visão essencialista a respeito das identidades, qualquer que seja o caso.
} 
Maria Celeste Mira

\section{Gêneros narrativos e mediação cultural}

A relação entre este aspecto da questão dos gêneros, o dos antagonismos $e$ aproximações entre os mundos masculinos $e$ femininos, pode ser pensada a partir dos gêneros narrativos que perpassam os meios de comunicação de massa. Para tanto, é preciso afastar-se de uma visão unilateral da mídia, que a coloca como um poder externo e imposto à sociedade. Os meios de comunicação de massa fazem parte da cultura moderna como um todo, existem numa sociedade de base tecnológica, com enormes aglomerados populacionais, gerida por instituições impessoais como o Estado e o mercado e, conseqüentemente, fortemente burocratizada. Mas uma sociedade também marcada por diferenças de classe, gênero, geração; atravessada por diversidades geográficas, étnicas e tantas outras. A comunicação deve ser entendida na sua relação com a cultura na sua acepção mais ampla, no sentido antropológico do termo, ou seja, como modo de vida. Esta foi a grande contribuição das Ciências Sociais para o estudo da comunicação. Foi Raymond Williams, em Marxismo e literatura, retomando as idéias de Gramsci, um dos primeiros a apontar a necessidade de pensar a cultura como modo de vida, dando início à fecunda corrente dos estudos culturais. ${ }^{5}$ Do lado da comunicação, dialogando com a anterior, os estudos passaram a matizar as considerações que viam a mídia como a única instância responsável pela produção de sentido, de um sentido único e de mão única. Neste campo, quem melhor formulou a idéia foi Jesus Martín-Barbero, quando disse que era preciso passar dos meios às mediações. Como salienta o autor, é necessário descobrir o sentido que os meios, bem como suas formas e aquilo de que falam, têm para as pessoas que os recebem, ou melhor, aquelas que, ao mesmo tempo, orientam sua produção. A recepção - citando novamente Martín-Barbero - não é um ponto de chegada, mas o lugar a partir do qual se pode

5 WiLliams, Raymond. Marxismo e literatura, Rio de Janeiro, Jorge Zahar, 1979. 
o deslocamento do olhar

compreender o processo de comunicação. Compreender gênero $e$ mídia dependeria, portanto, de situar a comunicação como parte de um processo de circularidade cultural. ${ }^{6}$

São várias e muito ricas as possibilidades de abordar o problema através dessa perspectiva conhecida como teoria das mediações. ${ }^{7}$ Grosso modo, poderíamos chamar de mediação todos os fatores, da produção à recepção, que estabelecem pontes entre estes dois termos. A própria produção pode ser entendida como mediação na medida em que organiza de determinada maneira os conteúdos e formas que passam por ela. Diversas outras mediações se interpõem $e$ articulam o produtor $e$ o receptor, o gênero, a geração, a classe social, as determinações do local, regional, nacional ou global, mas também a tecnologia, a imagem, a linguagem, o texto. Em relação a este último, pode-se dizer que cria entre produtor e receptor uma espécie de cumplicidade. Um não conhece o outro, mas sabe mais ou menos o que pode esperar dele. Entre eles estabelece-se como que um pacto ou contrato constituído por uma série de cláusulas, explícitas ou implícitas, por uma série de regras pré-estabelecidas. Quando alguém procura um filme de terror já sabe mais ou menos o que esperar e quando alguém o escreve também. $\mathrm{O}$ autor sabe o que o leitor está querendo, ou melhor, ele imagina. E é a esse leitor imaginado que ele se dirige.

Evidentemente, esse leitor imaginado não deixa de ser real. O real é sempre imaginado. Isto quer dizer que o emissor de um texto, seja de que natureza for, detém um saber sobre o seu

\footnotetext{
6 MARTín-BARBERO, Jesus. Dos meios às mediações: comunicação, cultura $e$ hegemonia. Rio de Janeiro, Editora da UFRJ, 1997; e América Latina e os anos recentes: o estudo da recepção em comunicação social. In: SouZA, Mauro Wilton de. (org.) Sujeito, o lado oculto do receptor. São Paulo, Brasiliense, 1995.

7 Luiz Signates chama a atenção para a diversidade de empregos do conceito de mediação e, com isso, para uma certa imprecisão do conceito. Mesmo assim, considero-o extremamente produtivo. Ver SIGNATES, Luiz. Estudo sobre o conceito de mediação. Novos Olhares, ano I, $\mathrm{n}^{\circ}$ 2, São Paulo, ECA/USP, $2^{\circ}$ semestre de 1998 .
} 
público, um saber que também o constitui como autor. O receptor penetra nele, na sua imaginação, seja por intuição, pesquisa de mercado ou ambos. Por sua vez, quem recebe a mensagem é penetrado pelo universo do autor. Mas não é aquele que apenas sabe o que esperar: o receptor também sabe ler. Sobretudo os fãs de determinado gênero, mas não só, desenvolvem, na prática, uma competência na leitura de determinados textos. Assim, tornam-se leitores cada vez mais exigentes, o que provoca mudanças na escritura.

Esse conjunto dinâmico de convenções que regulam o jogo entre o autor e o leitor é o gênero narrativo que articula as diversas maneiras de se contar uma história, ou melhor, as diferentes ênfases que se pode dar a determinados elementos ao se contar uma história. ${ }^{8}$ Estes dois debates e suas teorias normalmente se processam em separado, o primeiro sendo tratado pelos estudos de gênero das ciências sociais e o segundo nas escolas de comunicação. Foi neste último espaço, premido pela necessidade de explicar melhor a força dos produtos veiculados pela indústria cultural, que amadureceu uma nova teoria dos gêneros, desvinculada da teoria literária que lhe servira de inspiração inicial.

Segundo Jane Feuer, a noção de gênero na literatura é diferente da que se adota na ficção moderna. No primeiro caso, os gêneros emergiram e refletem determinados quadros culturais, abrangendo um largo espectro de produções: sua construção foi obra da crítica literária. No caso da produção de cinema e televisão o que ocorreu, de acordo com a autora, foi uma derivação do campo da literatura, a partir da qual determinados gêneros foram se configurando como tais pela designação da indústria e da crítica: sua formação é mais histórica do que teórica. Portanto, as abordagens estéticas do novo campo com as categorias do mundo literário podem levar a vê-los como distorções do padrão consagrado anteriormente. Mais fluída do

${ }^{8}$ Em inglês há duas palavras diferentes: gendere genre. 
o deslocamento do olhar

que na literatura, a noção de gênero pode ser aplicada até mesmo aos produtos não-ficcionais, de informação ou entretenimento. É possível, por exemplo, perceber no jornalismo a presença de normas do gênero policial ou de suspense, bem como de temas do melodrama nos reality shows. ${ }^{9}$

Numa tentativa de constituir uma teoria dos gêneros fímicos, Steve Neale contribuiu decisivamente para o debate contemporâneo. Seu ponto de partida foi a proposição clássica de Wladimir Propp para a análise estrutural dos contos de fadas. No cinema, como naquelas formas, a narrativa seria desencadeada pelo rompimento de uma situação inicial de harmonia $e$ desenrolar-se-ia em torno das peripécias do herói para restabelecê-la. Cada um dos gêneros, que o autor define como "modos de regulação", trabalha diferentemente com os elementos da narrativa para superar a desordem e restabelecer o equilíbrio. Neste trajeto, as potencialidades da narrativa são como que guiadas pelas regras do gênero. Como também é guiado o público: as pistas que se oferecem ao herói são também seguidas pelo espectador. Os gêneros, como resume o autor, são "um sistema de orientações que circulam entre a indústria, o texto e o sujeito". ${ }^{10}$

Um dos traços mais significativos dessa abordagem é que ela não desconhece o sujeito receptor, ao contrário da tradição frankfurtiana, para a qual tudo já estaria determinado no, e pelo, processo de produção. Não negligencia, porém, o caráter industrial da produção e suas determinações. De um lado, os gêneros orientam a produção uma vez que se definem por um

9 Desenvolvi esse ponto no artigo Entre o circo e a novela: formas e gêneros nos programas não ficcionais da TV. In: BoRELl, Silvia. H.S. (org.) Gêneros ficcionais, produção e cotidiano na cultura popular de massa. São Paulo, Intercom/CNPq/Finep, 1994. Ver também STAM, Robert. O telejornal e seu espectador. Novos Estudos, n 13, São Paulo, Cebrap, outubro de 1985.

${ }^{10}$ NeAle, Steve. Genre. Londres, British Film Institute, 1987. Ver também Borelli, Silvia. H.S. Ação, suspense, emoção. Literatura e cultura de massa no Brasil. São Paulo, Estação Liberdade/Educ/Fapesp, 1996. 
conjunto de convenções, de regras, mais ou menos fixas, que fornecem à indústria um formato que permite a reprodução, a serialização, o investimento num mercado já conhecido. De outro lado, as normas dos gêneros circulam também pelo texto, trilhando os caminhos da narrativa, definindo escolhas numa, mais ou menos ampla, gama de possibilidades. Finalmente, as regras do gênero pertencem ao domínio do espectador. Como explicou David Bordwell, "nenhuma história conta tudo". ${ }^{11} \mathrm{O}$ plano de narração de um filme - ou de uma novela, poderíamos acrescentar - não coincide com a história em si. As alterações cronológicas e espaciais revelam certos acontecimentos ao espectador e ocultam outros, um corte de imagem pode significar uma volta ao passado e assim por diante, de tal forma que a história é algo que se forma na mente do espectador através de uma leitura competente do texto apresentado. É certo que o texto traz em si os limites desta interpretação, mas, de fato, nesta perspectiva de análise, o espectador deixa de ser visto como sujeito passivo de um sentido que lhe é imposto. Jesus MartínBarbero definiu-os bem: os gêneros são "estratégias de comunicabilidade" através das quais o autor busca estabelecer uma cumplicidade com o espectador, reconstituindo o seu mundo. Por sua vez, o leitor/espectador, lendo ou assistindo seu gênero preferido, adquire uma capacidade cada vez maior de decifração dos sentidos, às vezes múltiplos, que nele estão presentes.

Por isso, o gênero narrativo também pode ser pensado como um mediador, uma ponte que une produtores e receptores através de um texto. Ao fazer esta ligação com o público, o gênero abre caminho para encontrar o significado de certas formas culturais na vida cotidiana de determinados públicos. Diferentemente das obras eruditas, a cultura de massa, como

\footnotetext{
${ }^{11}$ Bordwell, D. The classical Hollywood style, 1917-60. In: BordwELL, David, STAIGER, Janet e THOMPSON, Kristin. The classical Hollywood cinema: film style and mode of production to 1960. Nova York, Columbia University Press, 1985.
} 
o deslocamento do olhar

expressou Edgar Morin, é consumida no correr das horas. ${ }^{12}$ Ligase o rádio do carro, sobretudo quando o trânsito está parado, lê-se a revista entre uma tarefa e outra, em casa ou no escritório, assiste-se à televisão em companhia dos filhos, ou não, talvez sozinho. A cultura de massa está presente no dia a dia das pessoas, na rua, mas principalmente em casa, tendo os seus aparelhos transmissores confundidos com os outros eletrodomésticos da casa. Esse cotidiano é mais uma mediação, ou melhor, um conjunto de mediações, dentre as quais, uma das mais relevantes diz respeito às relações de gênero. Nada melhor para exemplificar esta articulação entre gender e genre do que a relação entre as narrativas românticas e o público feminino.

\section{Romance, melodrama e construção da identidade feminina}

Desde o final do século XVIII, quando as mulheres, na Europa, começam a ler, sua relação com o romance logo se estabelece. Como esclareceu Ian $\mathrm{Watt}^{13}$, apenas nos centros urbanos, sobretudo nas camadas alta e média, cresce muito o ócio feminino: a mulher não pode se ocupar de negócios ou qualquer outro trabalho fora do lar, bem como dos lazeres ao ar livre do mundo masculino, ao mesmo tempo em que, com as novas comodidades da vida na cidade, se desobriga de muitas tarefas árduas de antigamente. Ao lado dos trabalhos manuais, a leitura do romance e da poesia ocupa esse tempo vazio. Mais do que isto, o sucesso dos romances deveu-se ao fato de serem do interesse das leitoras. Seu enredo desenvolve-se praticamente em torno da história de um amor ou de um namoro, conduzindo a um casamento, num momento em que, como se sabe, este último ainda é a única opção de vida para as mulheres. Nesse período em que, segundo Watt, as mulheres adquirem maior liberdade na

\footnotetext{
${ }^{12}$ Morin, Edgar. Culturas de massas no século $X X$. Rio de Janeiro, Forense/ Universitária, 1975.

${ }^{13}$ WATt, Ian. A ascensão do romance. São Paulo, Companhia das Letras, 1990.
} 
escolha de seus maridos, devido ao individualismo emergente, mas no qual, simultaneamente, o casamento é cercado de convenções sociais e interesses econômicos, o romance tematiza apaixonadamente esse conflito. Entra no interior da personagem, investiga seus pensamentos, suas dúvidas, suas emoções. Mas, para fazê-lo, o gênero teve que libertar o sentimento que une um homem a uma mulher da idéia do amor cortês, fatalmente adúltero, e associá-lo ao casamento, ou seja, ligá-lo ao "amor romântico". É bem verdade que muitas heroínas dos romances se viram às voltas com o adultério, exatamente por causa dessa inadequação entre amor e casamento... E como sofreram!

No início do século XIX, o surgimento de uma imprensa de massa se baseará em boa parte no sucesso de um produto também ligado ao público feminino, o folhetim, fusão histórica do romance burguês com o melodrama popular que constituirá, por sua vez, a base de todas as formas narrativas audiovisuais, especialmente o cinema. A enorme importância do folhetim reside no fato de ter sido o veículo mediador entre as narrativas oriundas da cultura oral e da cultura clássica tradicionais $e$ as da nascente cultura de massas ou de mercado. Nele confluem a corrente oriunda do romance e a corrente melodramática, com seus temas característicos como o mistério do nascimento, identidades falsas, perseguição da inocência, segundo Edgar Morin, heranças da tragédia grega e do drama elisabetano adaptadas ao quadro urbano moderno. ${ }^{14}$ Essas duas correntes, segundo o autor, seriam responsáveis pela construção dos mecanismos de identificação e projeção que prendem o espectador à ficção de massa. $\mathrm{O}$ romance é a primeira forma narrativa em que o personagem central é um indivíduo comum, que não é, mas poderia ser, o seu leitor. Aprofunda essa identificação o fato de o romance buscar a verossimilhança, o realismo da narração. A história do livro, muitas vezes, é baseada ou inspirada em fatos reais. Desde então, realidade e ficção já se interpenetram claramente no universo da

${ }^{14}$ MoRIN, E. Culturas de massas... Op. cit. 
o deslocamento do olhar

cultura de massas. A corrente melodramática seria responsável pelas relações de projeção, uma vez que, diferentemente do romance, nela, o fantástico, o extraordinário, o mágico, o sobrenatural, que não podem ser vividos pelo homem moderno senão na ficção, se mantêm como elementos de causa e efeito.

Os gêneros se constituem, assim, em matrizes culturais outra expressão usada por Martín-Barbero. São fórmulas ou estruturas narrativas que se repetem ao longo do tempo, mas atualizando-se. E, ao se atualizarem, continuam a fazer sentido na vida de um determinado segmento de público. O melodrama é, sem dúvida, uma das mais duradouras. Se repararmos bem, veremos que a sua estrutura básica, formada pelo vilão, a vítima, o herói e o bobo, que remetem a quatro gêneros, o terror, o drama, a aventura e a comédia, ainda sustenta a atual telenovela, até mesmo na sua característica mistura de drama e comédia que aparece no chamado núcleo cômico, não por acaso o núcleo popular. Suas possibilidades de atualização parecem inesgotáveis. Por exemplo, um tema fundamental do melodrama, o desconhecimento e conseqüente reconhecimento da paternidade. Nem mesmo a facilidade do exame de DNA nos dias de hoje conseguiu superá-lo, pois no melodrama sempre existe a possibilidade de os exames serem trocados ou algo semelhante. Isto indica que a matriz melodramática permanecerá atual enquanto fizer sentido para um certo público, no caso, as mulheres, principalmente as das classes populares.

A tradição do romance e do melodrama, já processadas pelo folhetim, marcam definitivamente o cinema, antes de mais nada, pela opção fundamental pela narrativa. No estilo clássico hollywoodiano, o filme sempre conta uma história. No entanto, o cinema, especialmente o norte-americano, elaborará uma nova síntese e, por sua amplitude, a transformará, no século XX, numa linguagem universal. Essa nova síntese, elaborada ao longo de décadas de experimentação, consistirá em trabalhar com as mesmas matrizes, mas com uma extrema economia de meios. Em outras palavras, o filme tem que fazer o que faz um romance ou 
um drama em pouco tempo, com poucas cenas, de forma muito clara, porque, diferentemente do livro, o espectador não pode voltar atrás. Isto faz com que no filme tudo se transforme em narrativa, desde o seu título, os créditos da abertura, a trilha sonora, a iluminação, a caracterização das personagens através de traços marcantes, etc. Essa experimentação não é só dos diretores, atores e produtores, mas também do público que, como vimos, decodifica todas essas mensagens e influencia sua elaboração.

Ao contrário do que às vezes se pensa, o cinema não foi menos melodramático e romanesco do que a televisão. Segundo David Bordwell ${ }^{15}$, 95\% das narrativas de Hollywood se constroem em torno de um relacionamento amoroso, heterossexual $e$ romântico. Este padrão hollywoodiano, que fortaleceu a narrativa folhetinesca com a magia da imagem em movimento, foi o ponto de partida para outras fórmulas audiovisuais - para a velha radionovela, invenção cubana de tal sucesso, que se tornaria o carro-chefe do rádio nos anos 40/50, para o cinema de lágrimas argentino e mexicano, ambos reveladores da especificidade melodramática da América Latina. O cinema foi ainda a matriz da fotonovela que surgiu como cine-romance, ou seja, como narrativa fotográfica de um filme em cartaz. Desprendendo-se do cinema, a fotonovela se autonomizou e construiu seu formato e seu imaginário próprios, além de estúdios de produção na Itália semelhantes aos de Hollywood. O advento da telenovela era só uma questão de tempo e não demoraria a superar as formas precedentes. ${ }^{16}$

Embora tenham também um público masculino - e este é especialmente o caso da telenovela brasileira - a radionovela, a

\footnotetext{
${ }^{15}$ BordWELL, D. The classical Hollywood Style... Op. cit.

${ }^{16}$ Ver ORTIZ, R.; RAMOS, J.M.O. e BORELLI, S.H. Telenovela: história e produção. São Paulo: Brasiliense, 1989; MIRA, M.C. e BorELl, S.H. Sons, imagens, sensações: radionovelas e telenovelas brasileiras. Revista Brasileira de Comunicação, vol XIX, n ${ }^{\circ}$, São Paulo, Intercom, janeiro/junho de 1996; e HABBERT, Angeluccia. A fotonovela: forma e conteúdo. Dissertação de Mestrado, São Paulo, USP, 1972
} 
o deslocamento do olhar

fotonovela e a telenovela são predominantemente femininas. A fórmula já havia sido descoberta no rádio: lágrimas, mulheres $e$ empresas que vendem sabão. A identificação das mulheres com as radionovelas era tal que as agências de publicidade de firmas como Gessy-Lever e Colgate-Palmolive montaram departamentos encarregados de produzi-las. Félix Caignet, o autor cubano de $O$ direito de nascer, possivelmente a mais famosa de todas, dizia escrevê-las para que as mulheres pudessem chorar, fato que remete, para além da exploração do sentimento amoroso e dos dramas familiares, característicos do gênero, à difícil condição feminina, principalmente naquela época, na América Latina e nas classes populares.

Fortemente influenciados pela radionovela, surgem dois formatos televisivos diferentes: a soap opera norte-americana e a telenovela latino-americana. A primeira, exibida semanalmente, apresenta uma fórmula narrativa de longuíssima duração que pode ficar no ar durante décadas, com um grande número de personagens, cujas vidas vão se desenrolando junto com as de seu público, com suas tramas e sub-tramas que vão se resolvendo $e$ criando novas intrigas, com um alto nível de redundância, pelo menos, para quem não assiste. Não menos redundante, a telenovela latino-americana conquistou um espaço diário na televisão e no seu horário nobre. Tal foi o seu sucesso que, em termos de hora-audiência, levou, nos anos 70, ao declínio da influência norte-americana, com certeza na televisão brasileira, possivelmente também em países como Argentina, Colômbia, Venezuela, México e outros, onde a telenovela, mais uma vez, tornou-se um dos principais produtos da indústria do entretenimento. ${ }^{17}$

Esse longo caso de amor entre as mulheres $e$ as narrativas romântico-melodramáticas atravessa, até o momento atual,

${ }^{17}$ Cf. STRAUBHAAR, Joseph, O declínio da influência americana na televisão brasileira. Comunicação e Sociedade, n 9, São Paulo, Universidade Metodista, junho de 1983. 
a história de todos os formatos e suportes modernos, estando presente também no desenho animado, em formas narrativas trazidas pelo videogame ou pelo computador. Esse relacionamento, como já sabiam as firmas de higiene e limpeza, é uma poderosa força de consumo. De acordo com Colin Campbell, desde o século XVIII, quando o espírito do consumismo moderno emerge da conjugação entre o romance, o amor romântico e a moda moderna difundindo o hábito de sonhar acordado. Porque o que as pessoas, em particular as mulheres, desejam consumir, através dos produtos que são encorajadas a comprar, é a experiência romântica que leram nos livros ou assistiram nas telas, grandes ou pequenas, não importa. ${ }^{18}$

O consumo de produtos ou de narrativas é algo que se processa nas escolhas do dia a dia, escolhas estas que acabam constituindo um determinado estilo de vida, que constroem o senso de identidade que as pessoas formam sobre si mesmas. Como vimos, um dos motivos da força das narrativas românticas é que eles penetram no cotidiano das mulheres. Elas vão chorar com $O$ direito de nascer, no rádio ou na televisão, enquanto lavam a roupa ou fazem o almoço, fingindo que as lágrimas são por causa do sabão ou da cebola. Essa relação tão íntima e de tão longa data não pode ser vista como mera alienação. O romance e a novela são constitutivos da história da mulher ocidental moderna. Mais amplamente, os gêneros narrativos não são impostos pela mídia, mas fazem parte da construção social das diferenças entre homens e mulheres na modernidade.

Numa linguagem mais atual, pode-se afirmar que a expectativa da felicidade amorosa romântica torna-se parte da construção da identidade feminina. E, se como teorizou Anthony Giddens, o processo de construção da identidade no mundo moderno depende da elaboração de uma narrativa pessoal, podese concluir que a forma através da qual a mídia se integra à vida

${ }^{18}$ CAmpbell, Colin. A ética romântica e o espírito do consumismo moderno. Rio de Janeiro, Rocco, 2001. 
o deslocamento do olhar

cotidiana das pessoas passa, entre outras coisas, pelos gêneros narrativos. Dito de outra maneira, as narrativas do cinema, da televisão, da literatura de massa se entrelaçam com as narrativas da vida real, inclusive com aquela que alguém elabora sobre si ao construir a sua própria identidade. ${ }^{19}$ Algo semelhante pode ser observado na relação dos homens com alguns outros gêneros.

\section{Gênero pornô e identidade masculina}

Seja na literatura, no cinema, na televisão ou nas revistas, os temas e fórmulas que capturam o consumidor masculino são quase sempre os mesmos: a aventura, a violência - bases, por exemplo, do gênero policial - e o erotismo. Normalmente, nos produtos culturais mais bem-sucedidos junto ao público masculino, há uma característica mistura desses elementos. Mas nenhum outro é tão tipicamente masculino quanto o gênero pornô. Segundo Montgomery Hyde, a pornografia diz respeito aos homens desde a Antiguidade.$^{20} \mathrm{Na}$ sociedade burguesa, o fato não mudou, mas reforçou-se com uma concepção de casamento que reservou à vida conjugal uma sexualidade o mais pudica possível, lançando para o espaço da rua, dos bordéis e das publicações clandestinas a possibilidade de uma sexualidade mais erotizada, mais transgressiva. Ao expressar certas fantasias sexuais que não encontram lugar no casamento, mas que circulam pelo imaginário de uma determinada época, o gênero pornô acaba estabelecendo uma cumplicidade masculina entre os produtores e seu público. Novamente, o intermediário é um texto que reitera códigos de decifração já consagrados e, portanto, compartilhados.

$\mathrm{O}$ que une os temas masculinos é sua ênfase na ação. No caso da aventura e da violência, esta característica é mais

${ }^{19}$ GIDDENS, Anthony. Modernidade e identidade pessoal. Lisboa, Celta, 1997.

${ }^{20}$ Hyde, Montgomery. Historia de la pornografia. Buenos Aires, La Pléyade, 1973. Não entrarei aqui no mérito da discussão sobre as diferenças entre erotismo e pornografia, termos que estou usando, para os efeitos deste texto, praticamente como sinônimos. 
evidente. No gênero pornô, os analistas observam tratar-se também de uma narrativa pobre em densidade psicológica das personagens ou em expressão dos sentimentos, direcionando-se o máximo possível para a ação, o ato sexual. A esta se articula outra característica não menos importante: a regra de ouro do gênero pornográfico é a visualidade, é a presença do corpo feminino, nu ou seminu, oferecido como objeto de prazer ao olhar masculino. ${ }^{21}$ $\mathrm{O}$ voyeurismo é um traço que percorre toda a história do gênero pornô, desde os stag films, também conhecidos como voyeur films, passando pela pornochanchada, o filme e o vídeo eróticos, as revistas pornográficas ou os sites da Internet.

Ação e visualidade se conjugam para dar ao gênero pornô, ainda hoje, na grande maioria de sua produção, a realização imaginária do homem potente e da mulher impotente, do homem ativo e da mulher passiva. Vários autores já observaram que no filme, no vídeo ou na revista pornô, o ponto de vista adotado pela câmera é masculino. Ele é o sujeito, ele age, ele vê a mulher, ele vê o próprio orgasmo. $O$ prazer masculino se evidencia visualmente, principalmente no momento do money shot, a ejaculação para a câmera, mais uma convenção fundamental do gênero. Enquanto isto, a mulher geme, sussurra, grita. Mary Ann Doane sugere que a função desses sons teria a ver com a invisibilidade do prazer feminino. ${ }^{22} \mathrm{E}$ mais, enquanto a visão seria um sentido voltado para o exterior, a audição remeteria para o interior, para os sentimentos, para a psicologia da personagem, correspondendo, como vimos, às preferências da platéia feminina.

Não apenas no gênero pornô, mas em todos tipicamente masculinos, predomina a ação e o sentido da visão. Nos

${ }^{21}$ ABREU, Nuno Cesar. O olhar pornô: a representação do obsceno no cinema $e$ no vídeo. Campinas, Mercado de Letras, 1996; "I buy it for the articles". Playboy magazine and the sexualization of consumerism. In: DINES, Gail e HUMEZ, Jean. (orgs.) Gender, race and class in media. Londres, Sage, 1995.

${ }^{22}$ DOANE, Mary Ann. A voz no cinema: a articulação de corpo e espaço. In: XAVIER, Ismail. (org.) A experiência do cinema: uma antologia. Rio de Janeiro, Graal/ Embrafilme, 1983. 
o deslocamento do olhar

femininos, a narração e a audição. À predileção dos homens pela ação corresponde a das mulheres pela narração, pela discussão dos sentimentos, pelos debates comportamentais. Além das novelas, isto se explicita também nas revistas femininas, onde prevalece o texto, seja como debate, entrevista, fofoca, conselho, horóscopo, etc. Revistas de comportamento, espécie de psicologia popular, vendem milhões de exemplares, ao passo que nenhuma tentativa de revista de nu masculino teve grande sucesso entre as mulheres, nem mesmo na Suécia, país conhecido por sua liberalidade de costumes. ${ }^{23}$ Parece que às mulheres raramente interessa ver apenas o corpo nu, possivelmente porque um homem vestido traz mais informações sobre o seu interior, sua maneira de ser. Em outros termos, não é que as mulheres não se interessem por sexo, é que elas preferem ouvir e falar do que ver. Evidentemente, essas preferências são históricas, relacionam-se à cultura sexual no sentido amplo da expressão ou, na expressão de Peter Gay, à educação dos sentidos. ${ }^{24}$ Assim como aos homens não são permitidas as lágrimas, às mulheres não foi ensinado o olhar erótico ou pornográfico.

No mundo moderno, um momento claro desta ruptura se dá com a ascensão dos valores burgueses e da imprensa de massa. Até o século XVIII, as revistas de moda traziam duas figuras, a do homem e a da mulher, como modelos de um determinado figurino. Quando surgem as revistas femininas modernas, a figura do homem desaparece, ficando só a da mulher. ${ }^{25}$ Como demonstrou Gilda de Melo e Souza, o homem se retirou do universo da moda no século XIX. "Ser homem", naquele austero mundo burguês, significava abandonar os frufrus do homem da

23 ORFALI, Kristina. Um modelo de transparência: a sociedade sueca. In: Prost, Antoine e VINCENT, Gérard. História da vida privada 5. São Paulo, Companhia das Letras, 1992.

${ }^{24}$ GAY, Peter. A experiência burguesa da Rainha Vitória a Freud: a educação dos sentidos. São Paulo, Companhia das Letras, 1988.

25 Sullerot, Evelyne. La presse féminine. Paris, Armand Colin, 1963. 
nobreza para se destacar por seu poder, seus negócios e sua moralidade. Às mulheres burguesas, como vimos, só restava a alternativa do casamento. Para conquistarem seu futuro marido tinham que ser virtuosas, mas não ao ponto de não lhes chamar a atenção. As mulheres teriam desenvolvido, então, através da moda, toda uma técnica de sedução baseada na arte de mostrar e esconder seus predicados, inclusive os físicos. Esta arte não se restringia à vestimenta, mas à maneira de portá-la, desdobrandose em inúmeros gestos ligados aos véus, aos xales, aos leques $e$ etc. ${ }^{26}$ Estabelece-se, neste momento, a dinâmica do olhar que vigorará em todo o período clássico da indústria cultural, desde meados do século XIX até a metade do XX. Os olhares recíprocos entre homens e mulheres, que por certo havia nas sociedades de corte, desaparecem. A partir do século XIX, quando o homem é excluído do universo da moda, ele, o todo poderoso dono das mercadorias, olha; e a mulher, como dizia a revista Playboy, a mercadoria mais importante, é olhada. Mas as mulheres, por sua vez, desenvolvem uma verdadeira arte ou tecnologia da imagem. Fazem da moda e da beleza uma maneira de expressar, ao mesmo tempo, sua individualidade e sua adaptação às convenções da sociedade. Aprendem a manipular o olhar masculino, o das outras mulheres e o seu próprio. Acabam achando prazer em se ver e em imaginar-se sendo vista pelos outros. $^{27}$

À medida que as construções da identidade pessoal e social, masculina e feminina, se deslocam, ao longo de todo este período, os produtos da indústria cultural vão mudando com eles. Nos anos 20, dá-se o que Gilles Lipovetsky denominou o "boom da beleza", explosão da indústria de cosméticos e outros fatos correlatos. ${ }^{28} \mathrm{~A}$

${ }^{26}$ SouZA, Gilda de Melo e. O espírito das roupas: a moda no século dezenove. São Paulo, Companhia das Letras, 1987.

${ }^{27}$ RADNER, Hilary. Shopping around. Feminine cutlure and the pursuite of pleasure. Londres/N. York, Routledge, 1995.

${ }^{28}$ LIPOVETSKY, Gilles, La troisième femme: permanence et révolution du féminin. Paris, Gallimard, 1997. [NE: Existe tradução para o português - A terceira 
o deslocamento do olhar

aparência corporal passa a ter cada vez mais importância, porém, muito mais para as mulheres do que para os homens. A beleza, definida sob novos padrões, divulgados pelo cinema hollywoodiano, pelas revistas e pela publicidade, torna-se, ao lado da moda, um elemento central na construção da identidade feminina, o que mantém inalterada a dinâmica do olhar observada no século XIX. Pouco depois se consolida nos Estados Unidos a receita clássica da revista masculina. Playboy é criada por Hugh Hefner em 1953. Se as revistas de cinema mostravam às mulheres os rostos de seus ídolos, as masculinas já exploravam sua nudez. O impacto da primeira edição de Playboy, que parece ecoar até hoje, deveu-se reconhecidamente à famosa capa com a atriz Marylin Monroe nua sobre um fundo vermelho. A revista primou por seus artigos, exploração do consumo e do estilo de vida, mas o que não pode faltar são os ensaios fotográficos. ${ }^{29}$

Essa é a diferença entre Playboy e Cosmopolitan, sob este aspecto, uma das mais ousadas receitas de revista feminina. Criada nos anos 60, para uma mulher mais independente, que tem uma vida profissional fora do lar, que deseja uma vida sexual feliz, que tem seu próprio dinheiro, não consegue romper, no entanto, a dinâmica do olhar masculino. Cosmopolitan traz inúmeras matérias sobre sexo, constituídas de páginas e páginas de texto, com uma ou outra ilustração. Na revista que se apresenta ao mundo inteiro como a da nova mulher, a imagem predominante ainda é a dela própria; o corpo do homem não aparece como objeto do seu desejo.

\section{Gênero e geração: o deslocamento do olhar}

mulher: permanência e revolução do feminismo. São Paulo, Cia das Letras, 2000.]

${ }^{29}$ DINES, Gail. "I buy it for the articles". Playboy magazine and the sexualization of consumerism. In: DINES, Gail e HuMEZ, Jean. (orgs.) Gender, race and class in media. Londres, Sage, 1995. 
Como a relação entre homens e mulheres, as regras dos gêneros narrativos também se transformam; elas mudam, por exemplo, de uma para outra geração. Um ótimo exemplo desse movimento é o percurso histórico da revista Capricho. Criada em 1952, ela foi a mais bem sucedida revista de fotonovelas do Brasil, chegando a tirar meio milhão de exemplares por mês. Trazia a tendência mundial da narrativa fotográfica romântica, lacrimosa, onde a mocinha era sempre a vítima, passiva e sofredora, que só seria feliz no último quadrinho. Mas também seguindo tendência mundial, em meados dos anos 70, ela entra em declínio. Poder-seia argumentar que a fotonovela estava apenas sendo trocada por outro formato, a telenovela. Mas, de fato, ela era substituída, principalmente, por uma nova visão de si que as mulheres, pelo menos as de classe média, começavam a construir por influência da difusão do movimento feminista pela própria mídia, em particular a impressa, a revista feminina. Há vários trabalhos que mostram a absorção e a interpretação do feminismo por parte das revistas femininas. ${ }^{30} \mathrm{~A}$ própria telenovela brasileira passa nesse momento por uma transformação, afastando-se da matriz melodramática característica de seu período inicial. Ela vai tornarse mais realista e com isso conquistar também um público masculino, os segmentos jovens e tantos outros, tornando-se o fenômeno de massa de maior expressão no Brasil.

O declínio da fotonovela e a transformação da telenovela nos anos 70 também podem ser interpretados à luz da teoria dos gêneros narrativos. Segundo Steve Neale, a especificidade de um gênero é o resultado da combinação particular de elementos que ele, na verdade, compartilha com todos os demais. Assim, por exemplo, no melodrama, o amor heterossexual adquire um papel central, definindo a motivação dos personagens principais, ao

\footnotetext{
${ }^{30}$ Ver, entre outras, BASSANEZI, Carla. Virando as páginas, revendo as mulheres. Revistas femininas e relações homem-mulher 1945-1964. Rio de Janeiro, Civilização Brasileira, 1996; e CASTRO, Ana Lúcia de. Revistas femininas: aspectos históricos, produção e usos sociais. Dissertação de Mestrado, São Paulo, PUC, 1994
} 
o deslocamento do olhar

passo que no policial ou terror, embora a trama amorosa esteja presente, o tema da violência se sobrepõe. ${ }^{31}$ Isto faz com que as narrativas possam ser moldadas de forma a acompanhar as mudanças do seu público, a conquistar o outro sexo ou as gerações mais jovens. No melodrama e em outras narrativas oriundas da tradição popular, como a literatura fantástica, é possível que as causas de um ou de muitos acontecimentos sejam sobrenaturais ou ditadas pela fatalidade, pelo destino. As narrativas que mais atraem o público masculino $e$ as gerações mais jovens são mais realistas, como vimos, no sentido de parecerem mais reais, de trabalharem com relações de causa $e$ efeito verossímeis aos olhos do homem moderno, mais racionalizado. Parece possível pensar que como essa mentalidade atingiu mais, e primeiro, aos homens, expostos antes à organização racional do trabalho, afastou-os mais depressa do imaginário tradicional que ainda fez sentido por muito mais tempo para as mulheres. Mas à medida que elas saem da esfera doméstica e adentram a vida pública, elas também se distanciam daquele mundo de contos de fada.

Esse afastamento indica que, nos anos 80 , já era possível, ou melhor, necessário, dirigir-se com mais realismo a uma mulher que estava mudando. Foi o que aconteceu com Capricho. A pesquisa de Ana Lucia de Castro revelou que as leitoras escreviam descontentes para a redação da revista, reclamando das fotonovelas que consideravam "água com açúcar" ou "historinhas do tempo da vovó". A revista tentou durante mais ou menos dez anos, entender e se comunicar com as mulheres adolescentes, não as únicas, mas as principais leitoras de fotonovela. As vendas não pararam de despencar até que se encontrou, em 1985, a receita editorial batizada de "revista da gatinha". Um dos ingredientes da nova fórmula foi a substituição da fotonovela pelas reportagens sobre os ídolos daquela geração no universo da música, do cinema ou da tevê, o que Angela McRobbie chamou de

${ }^{31}$ Neale, S. Genre. Op. cit. 
"romantismo pop" ${ }^{32}$ Mas é importante notar que esse tipo de revista não fala às meninas diretamente sobre música, cinema ou televisão. Fala, sobretudo, da vida pessoal e sentimental dos artistas. Transforma-as em narrativas extraídas da vida real que seguem muitas vezes as regras dos gêneros. Joke Hermes observou em relação às revistas de fofocas a presença da matriz melodramática: as pessoas acompanham a vida das celebridades como se fossem intermináveis novelas. Através desses relatos, de fotografias e autógrafos colecionados, de cartinhas enviadas, as adolescentes estabelecem, segundo a mesma autora, um vínculo amoroso com seus ídolos. As "gatinhas" dos anos 80/90 continuavam românticas, porém sonhando ainda mais acordadas do que as mocinhas dos anos 50/60.

Porém, o mais importante é que se delineia a partir de então uma mudança no jogo de olhares masculinos e femininos. A mulher jovem de classe média dos anos 80 já não se identifica tanto com a heroína da fotonovela, passiva porque predestinada a ser feliz. Ela é mais atrevida, título de uma das revistas criadas na época para este segmento. O melhor índice dessa mudança parece ser a sua relação com a imagem do corpo masculino. Distantes de suas avós ou mães que se maravilhavam com o rosto de seus astros mais queridos, as gatinhas dos anos 80 vêem seus gatos em poses de corpo inteiro, bem mais sensuais, com ênfase no tórax, nas virilhas, nos braços musculosos, não de todo nus, mas cada vez com menos roupa. Isto parece indicar que essas mulheres estejam aprendendo a olhar para o corpo masculino, começando a romper a histórica barreira criada pela dinâmica da primazia do olhar masculino. Revistas femininas mais recentes, como TPM, trazem ensaios fotográficos onde o corpo masculino aparece mais ainda. A maioria dos homens aparece sem camisa, com calças de cintura bem baixa, puxando o olhar feminino para os genitais. Até um nu masculino já aconteceu, com o roqueiro Supla, de

32 McRobBIE, Angela. Feminism and youth culture. From Jackie to Just Seventeen. Londres, MacMillan, 1991. 
o deslocamento do olhar

costas. ${ }^{33}$ As coisas parecem estar mudando rapidamente, mas as mulheres ainda não são as compradoras de revistas de nu masculino. Aquelas que o publicam são dirigidas e adquiridas na sua quase totalidade pelo público gay.

Do lado dos homens, também ocorrem transformações. A partir das duas últimas décadas do século XX, começa a emergir, ao menos nos meios mais urbanizados, o que tem sido chamado de uma "nova masculinidade", na qual, um dos aspectos mais relevantes é a preocupação com a própria imagem, domínio até então reservado às mulheres. Essa nova masculinidade derivaria de uma mudança de orientação da ética do trabalho para a do prazer entre os homens jovens das classes altas, teria a ver com a expansão do mundo da arte nas grandes metrópoles ou com a ampliação das possibilidades de estetização da vida cotidiana. Mas deve-se ainda investigar melhor o quanto ela deve ao movimento gay, onde se difundiu primeiro o culto da imagem masculina, mas, principalmente, onde se desenvolveu o olhar dirigido ao homem, o olhar que tem como objeto de desejo o corpo masculino. A partir dos anos 90, o setor de publicidade que mais crescia nas revistas masculinas era o de moda. As estatísticas já mostravam que os homens estavam procurando, cada vez mais, cuidados estéticos e de rejuvenescimento de todos os tipos.

Se os homens não se preocupavam quase nada com a sua imagem era porque ela não estava em questão. Esta dinâmica do olhar unilateral do homem para a mulher, fez com que, nos gêneros voltados para o público masculino, inclusive no pornográfico, onde a nudez é regra, o corpo masculino raramente se expusesse como o da mulher, a não ser para mostrar sua potência. $O$ corpo masculino aparece sempre em ação, conquistando espaços, superando obstáculos, medindo forças, lutando e dominando pessoas, animais, monstros, extraterrestres ou o que quer que se oponha ao alcance de seus objetivos. Como

${ }^{33}$ TANIO, Maria Cristina. Mulheres de TPM: construindo modelos de identificação. Dissertação de Mestrado, São Paulo, PUC-SP, 2003. 
se nota, os gêneros voltados para os homens, como os romances de aventura, policial ou terror, são muito semelhantes ao universo dos esportes, tradicionalmente muito mais masculino. Mais uma vez, estamos diante de algo que subsidia diversos produtos da indústria cultural: os espetáculos esportivos, programas de rádio e televisão, jornalismo, moda esportiva. De novo, a ênfase se coloca na ação e na visualidade.

Da mesma forma que o romantismo persiste nas revistas $e$ na ficção femininas dirigidas a gerações mais jovens, a ação $e$ a competição continuam a estruturar os produtos voltados para os jovens e adolescentes do sexo masculino. Elas são dominantes no cinema, na televisão, nas revistas, mas também nos quadrinhos, nos desenhos animados, nos videogames e em muitos outros produtos. Essa supremacia da ação pode estar ligada ao que John Fiske denominou a "prova da masculinidade", ou seja, à necessidade de mostrar certos padrões de virilidade o tempo todo. ${ }^{34}$ Para o autor, a sociedade moderna continua concebendo o sexo masculino como superpotente e auto-suficiente, um ideal que só pode se realizar imaginariamente. $\mathrm{O}$ que os homens encontrariam nos esportes e narrativas de aventura seria uma realização simbólica dessa masculinidade inalcançável. Para os jovens e adolescentes, essa problemática, longe de desaparecer, se tornaria crucial. Se a masculinidade nunca pode ser dada por garantida, nessa idade de busca e experimentação de identidades, ela é constantemente posta a prova. Parece até mesmo se prolongar em função do desaparecimento dos rituais de iniciação que, nas sociedades tradicionais, fazem a passagem definitiva dos meninos para o mundo dos adultos do sexo masculino.

Parece claro que a relação dos homens com a ação é muito forte, talvez imemorial. Na grande maioria das sociedades tradicionais, as tarefas masculinas exigem um deslocamento maior no espaço do que as femininas, o que explicaria seu vínculo maior com o tema. Mas as mudanças trazidas pela modernidade são

${ }^{34}$ FISKE, John. Television culture. Londres/Nova York, Methuem, 1987. 
o deslocamento do olhar

extremamente profundas, notadamente no que se refere às relações entre homens e mulheres. Assim como a moda e a aparência pessoal já preocupam bastante os homens, o mundo da ação, da aventura e dos esportes, começa a fazer parte dos interesses femininos. Alguns esportes muito masculinos, como o futebol, por exemplo, expandem-se entre as mulheres, dentre as quais já há, além das jogadoras, as juízas, repórteres e comentaristas. Outro exemplo, ainda não consolidado, mas que aponta numa direção importante, é Fluir Girls, edição especial da revista Fluir, dedicada ao surf. Ainda que acoplada à moda, à beleza e ao estilo de vida, aspectos que o segmento do surfjá vem explorando há décadas, trata-se - fato inédito - de uma revista de esporte destinada ao público feminino. Parece possível afirmar que as mulheres descobriram que o esporte pode favorecer a beleza e a boa forma e ser um elemento de estilo interessante, ao passo que os homens chegaram ao cultivo da aparência pela via dos esportes. Afinal, como observou John Fiske, nas narrativas eróticas como nas imagens esportivas já estava implícita a beleza do corpo masculino em ação. ${ }^{35}$ Nos dois casos, o denominador comum é o corpo, aspecto cada vez mais central na construção das identidades de homens e mulheres.

${ }^{35}$ ID., IB. 